\title{
Na marginesach filozofii
}

Redaktorzy: Może teraz przeszlibyśmy do spraw bardziej związanych z filozofia. Pamięta Pan jeszcze, jak to jest nie być pragmatystą?

Richard Rorty: Rozpaczliwie chciałem być platonikiem - zjednoczyć się z Bytem, połączyć z Chrystusem, Bogiem, platońską ideą Dobra bądź czymś w tym rodzaju. Pragmatyzm był swego rodzaju reakcją na to.

Kiedy zaczą Pan mieć watpliwości co do tego platońskiego idealizmu?

Przed trzydziestką. Byłem już wtedy po studiach i przez jakiś czas pracowałem w biznesie.

Lecz wydaje sie - o ile moje przekonania co do Pańskiej historii akademickiej nie sa wypaczone - że w latach pięćdziesiątych i sześćdziesiątych wciąz pisał Pan w duchu dość prostej filozofii analitycznej.

${ }^{*}$ Pełen tekst tłumaczenia dostępny jest w drukowanej wersji pisma. 
Nie do końca tak było. Swoją pierwszą pracę dostałem na Wellesley, gdzie uświadomiłem sobie, że zostałem źle wyedukowany, by móc wykładać filozofię w Stanach Zjednoczonych. Filozofia analityczna zaczynała dominować. Lecz uczelnia, którą ukończyłem, nie zauważała tego faktu i również ja nie poświęciłem filozofii analitycznej wystarczająco dużo uwagi. Kiedy znalazłem się na Wellesley, dostrzegłem, że wszyscy moi koledzy przeszli na Harvard i znali na bieżąco Quine’a, ale również Austina. Więc również i mnie pochłonęły prace Quine'a, Wittgensteina, Austina, to czytali wszyscy moi koledzy. Dlatego i ja dokształcałem się, by móc stać się filozofem analitycznym. (...)

P R Z E Ł O Z Y Ł S Ł A W O M I R D R E L I C H 